\title{
Therapeutic Effects of Turnera diffusa Extract Against Amitriptyline-Induced Toxic Hepatic Inflammation
}

\author{
${ }^{1}$ Ahmed F. Hasan, ${ }^{2}$ Thulfiqar F. Mutar, ${ }^{3 *}$ Ehab Moustafa Tousson and ${ }^{4}$ Shatha Ghazi Felemban \\ ${ }^{l}$ Department of Biology, Al-Farabi University College (FUC), Al-Dora Square, Al-Masafee Street, Baghdad, Iraq \\ ${ }^{2}$ Department of Medical Laboratory Techniques, Al-maarif University College, Al-anbar, Iraq \\ ${ }^{3}$ Department of Zoology, Faculty of Science, Tanta University, Egypt \\ ${ }^{4}$ Medical Laboratory Science, Fakeeh College for Medical Science, Jeddah, Saudi Arabia
}

\author{
Article history \\ Received: 25-04-2021 \\ Revised: 03-06-2021 \\ Accepted: 15-06-2021 \\ Corresponding Author: \\ Ehab Moustafa Tousson \\ Department of Zoology, \\ Faculty of Science, Tanta \\ University, Egypt \\ Email: toussonehab@yahoo.com
}

\begin{abstract}
Tricyclic Antidepressants Including Amitriptyline (AMI), stop the reabsorption of norepinephrine and serotonin, so the levels of transmitters is elevated in the brain to lead to several side effects. Therefore, current study aimed to assay liver dysfunction that attended by AMI administration and monitoring of damiana Turnera diffuse role as adjuvant therapy to improving amitriptyline hepatic effects in male rats. 60 rats (adult, male, albino) were used divided into six groups ( $n=10)$; 1st group, control; 2nd group, damiana; 3rd group, AMI; 4th group, co-treated AMI with damiana; 5th group, posttreated AMI with damiana and 6th group, self-healing AMI. Results showed that; AMI induces an elevation in AST, ALT and ALP; while it reduced albumin and total protein content. Besides, autoimmune liver disorders (ANA), hepatic DNA damage, p53 and PCNA protein expressions and histopathological injury were detected. However, the groups administered with damiana showed positive effects by increasing cellular response and reducing pathological changes. It concluded that treatment with AMI causes liver dysfunction, while damiana can: Protective against the toxic effects induced by AMI in rats.
\end{abstract}

Keywords: Amitriptyline, Turnera diffusa (Damiana), Liver Toxicity, Proliferation, Apoptosis

\section{Introduction}

Despondency is quite possibly the most well-known illnesses among individuals, so antidepressants are perhaps the most well-known mental drugs endorsed to patients on the planet, regardless of their many results (Tondo and Baldessarini, 2016). Discouragement is related with specific synthetic compounds in the cerebrum called synapses and when taking antidepressants, they decrease the seriousness of melancholy by influencing these synapses. Amitriptyline (AMI) has a place with a gathering of antidepressants called "tricyclic antidepressants" and is generally used to treat gloom (Häuser et al., 2011).

AMI expands execution, invigorates active work, improves craving and reestablishes revenue in day by day exercises. Likewise, AMI is endorsed to help forestall headaches or to assist with particular sorts of nerve torment. (Neuropathic torment, fibromyalgia), ongoing torment, consideration Deficiency Hyperactivity issue (ADHD), tension problems and bedwetting in youngsters (nighttime enuresis) (Vlainich et al., 2011).
Cyclic antidepressants assuage misery by influencing the synthetic couriers (synapses) that synapses use to speak with one another (Mika et al., 2013). Amitriptyline causes a fast pulse and perhaps heart failure, just as cardiovascular poisonousness, myocardial rot and cardiovascular troponin rise in rodents (Basol et al., 2019). At times, the portion of AMI might be expanded for discouraged patients due to a misdiagnosis of some vague manifestations like loss of hunger, weakness, sickness and stomach torment as indications of despondency, while they are side effects of hepatic injury brought about by the amitriptyline. AMI invigorates lipid peroxidation and Receptive Oxygen Species (ROS) in liver cell layers and testicular tissues that block development because of their impedance with metabolic cycles (Bautista-Ferrufino et al., 2011; Tousson et al., 2020a).

Various investigations have been centered around recognizing distinctive normal items in the clinical field for the treatment of an assortment of illnesses (Aldubayan et al., 2019; El-Masry et al., 2019; 2020; Alotaibi et al., 2020, 2021; Altwaijry et al., 2020; 2021). Additionally, phytochemicals were affirmed to be 
protected and possibly valuable therapeutically (Abd et al., 2020; Tousson et al., 2018; 2019).

Additionally, Turnera diffusa Willd (damiana) is discovered plentifully in parched and semiarid areas like Mexico, Bolivia, Brazil, Central America and South America and it is utilized in elective medication in view of its remedial and viable properties against numerous illnesses, just as it was utilized as a sexual energizer and diuretic and its entrance into numerous drug items (Alcaraz-Melendez et al., 2007; Estrada-Reyes et al., 2016; Tousson et al., 2020b).

Damiana contains numerous therapeutic properties since it has cancer prevention agents and flavonoids and in this way it can assume a viable part to diminish the oxidative stress and free revolutionaries brought about by certain medications and harmful mixtures (Piacente et al., 2002; Estrada-Reyes et al., 2013; Zhao et al., 2007). Through the helpful properties of damiana, it was discovered that there is an incredible interest by the drug organizations to profit with the dynamic substances found in damiana and use them in numerous drug arrangements and clinical enterprises (Garza-Juárez et al., 2011; PeRez-Meseguer et al., 2010).

The liver is perhaps the main organs in the digestion of food or substance, as it attempts to use all medications that enter the body, particularly through the stomach related framework, so it is important to screen the medication's consequences for the liver (Saggu et al., 2014; Al-Rasheed et al., 2018; Abd Eldaim et al., 2021).

Along these lines, this article expected to uncover the damages of utilizing the upper AMI and its impact on liver movement and delineation the job of damiana concentrate to improve and decrease the hepatotoxicity-instigated by AMI in male rodents.

\section{Materials and Methods}

\section{Damiana Leaves Extract Preparation}

When the damiana leaves were gotten, they were washed well and dried in the stove at $65^{\circ} \mathrm{C}$. From that point forward, the dried leaves were squashed and placed in water. They were blended and put on a shaker for $24 \mathrm{~h}$ at room temperature to acquire watery damiana separate and put away in obscurity until use as indicated by LaLone et al. (2007).

\section{Amitriptyline and Orally Treatment}

Amitriptyline (AMI) tablets containing hydrochloride and economically known as (Tryptizolß) were bought from El-Kahira Pharmacological and Chemicals Company, Egypt. AMI was broken down in refined water and offered orally to rodents by a taking care of cylinder, where the portion was $(100 \mathrm{mg} / \mathrm{kg} \mathrm{BW})$ and the all out volume of the arrangement was $(2 \mathrm{ml} / \mathrm{kg} \mathrm{BW})$ as per (Bae et al., 2009; Hassanane et al., 2012).

\section{Animals}

The creature trial plan of this investigation supported by the Ethical Committee of the National Research Center, Egypt. Grown-up male pale skinned person rodents. 60 adult (male, albino, age 9-10 weeks and weight 150-170 g) rats were used in current study brought from National Research Center (Dokki, Giza, Egypt). Rats were allocated to six gatherings and housed in Universal electrifies wire confines at room temperature $\left(22-25^{\circ} \mathrm{C}\right)$ and in a photoperiod of $12 \mathrm{~h}$ /day. Rats were given a fair business diet and water gave not indispensable. All rodents were taken care of as per the standard guide for the consideration and utilization of research facility creatures.

\section{Experimental Groups}

Six groups of rats were distributed $(\mathrm{N}=10)$ as follows:

G1 (control group) not received any treatment.

G2 (damiana group) administrated with damiana extract orally $80 \mathrm{mg} / \mathrm{kg} \mathrm{BW}$ daily by a feeding tube for 28 days,

G3 (AMI group) administrated with AMI orally 100 $\mathrm{mg} / \mathrm{kg} \mathrm{BW}$ daily by a feeding tube for 28 days.

G4 (co-treated group) administrated with AMI and damiana orally for 28 days.

G5 (post-treated group) administrated with AMI orally for 28 days and followed with damiana treatment for successive 28 days.

G6 (self-healing group) receive AMI for 28 days and left without treatment for other consecutive 28 days

\section{Blood and Tissue Samples}

Toward the finish of the trial time frame, rodents were anesthetized by sodium pentobarbital and forfeited. The blood tests were gathered from the heart Vena Cava in clean glass cylinders and left to cluster at room temperature for ten min and afterward centrifuged at 3000 r.p.m for fifteen min. The serum was isolated in Eppen-dorf tubes and put away at $-60^{\circ} \mathrm{C}$ until utilized for biochemical investigation.

Rats liver tissues was painstakingly eliminated and fixed with $10 \%$ buffer neutral formalin for utilized in histopathological and immunohistochemical assessments and one gram of the rest tissues divide was utilized for the comet test.

\section{Determination of Liver Function Levels}

Both Aspartate Transaminase (AST) and Alanine Transaminase (ALT) exercises were examined as per the strategy depicted by Reitman and Frankel (1957). Albumin and total proteins contents in serum were assessed by the strategy for Doumas et al. (1997) and Bowers and Wong, (1980). Alkaline phosphatase in serum was assessed by the strategy for Belfield and Goldberge, (1971). 


\section{Measurement of Serum Antinuclear Antibodies (ANA)}

Enzyme - linked Immunosorbent Assay (ELISA) kits for the revealing of antinuclear antibodies (ANA) were gotten from Helix Diagnostics (West Sacramento, CA). Serum samples were diluted 1:100 (v/v) in assay diluent and assays were done according to the manufacturer's directions.

\section{Determination of Hepatic Tissue DNA Damage}

DNA damage analysis of all studied groups were done by comet test as indicated by Abd Eldaim et al. (2019); Tousson et al. (2020b).

\section{Histopathological Preparation}

After fixation of liver tissues in neutral buffer formalin $(10 \%)$, dehydration in increasing series of alcohol, cleaned well, embedded in paraffin, sectioned and, stained with Haematoxylin and Eosin (H\&E) for examined by using a light microscope (Tousson et al., 2012; Tousson, 2016).

Immunohistochemical Examination for p53 and PCNA

Detection of the p53 immunoreactivity (p53-ir; dilution 1:200) and PCNA immunoreactivity (dilution 1:100) from DAKO, Japan. with avidin Biotin Complex (ABC) (Elite, USA) as per Tousson et al. (2016; 2011).

\section{Statistical Analysis}

Information of the current examination were investigated with Statistical Set for the Social Sciences (SPSS Inc., USA), the investigation was done utilizing single direction ANOVA to decide the critical contrasts between the mean values \pm SE of the gatherings, the worth of $\mathrm{p}<0.05$ considered measurably huge for the biochemical information.

\section{Results}

\section{Liver Function Examinations}

Table 1 shows that serum ALT, AST and ALP levels are significantly $(\mathrm{P}<0.05)$ increased, while albumin and TP contents were significant reduced in rats treated with AMI alone and with self- healing as compared with the control and damiana groups. Furthermore, rats treated with damiana in co-treated and post-treated showed significant improvement in ALT, AST and ALP activities and protein contents when compared with the AMI group.

\section{Variations in Anti-Nuclear Antibody (ANA) Levels in Different Groups}

A significant increase in serum ANA levels were detected in the amitriptyline group (G3) when compared with control (G1) and damiana (G2) groups while an insignificant decrease in ANA levels in amitriptyline group when compared with self-treated amitriptyline (G6) group (Fig. 1).

On the other hand; treatment of amitriptyline treated with damiana (as co-or post) groups revealed a significant decrease in ANA levels when compared with the amitriptyline group. A significant decrease in serum ANA levels was detected in co-treated (G5) and post-treated (G6) amitriptyline with damiana group when compared amitriptyline and self-treated amitriptyline groups (Fig. 1).

\section{DNA Damage in Liver}

Comet assay evaluation of DNA damage in hepatic tissues among control and damiana groups shows no significant variations were spotted in values for tail length or in percentages for tailed, untailed, tail DNA and tail moment (Table 2 and Fig. 2A, 2B).

However, the treated with AMI showed a significant $(\mathrm{P}<0.05)$ elevation in hepatic DNA damage values for tail length and percentages for tailed, untailed, tail DNA and tail moment as compared to control and damiana groups (Fig. 2C).

In contrast, the presence of damiana in co-treated and post- treated groups induces suppression for hepatic DNA damage as compared with the AMI group (Fig. 2E, 2F). The ameliorating effect of damiana was more pronounced in the co-treated group.

\section{Histopathological Observations of Liver}

The histopathological examination of hepatic tissues in control and damiana groups revealed normal structure in hepatocytes, nucleus, central vein and sinusoidal with Kupffer cells (Fig. 3A, 3B). Whereas, the hepatic sections of rats that exposed to AMI alone and with self-healing display marked destruction of hepatocytes and blood sinusoidal, necrotic of the nucleus, congestion with cellular infiltration about central vein (Fig. 3C, 3D).

On the other hand, microscopic examination in the hepatic tissue of the co-treated group showed mild to moderate improvement in the structure of hepatocytes and slightest congest in central and portal veins and few cellular inflammations between lobes (Fig. 3E). The liver section in the post-treated group revealed moderate improvement in the structure of hepatocytes, blood vessels with Kupffer cells, also the normal structure of central and portal veins (Fig. 3F).

\section{P53 Immunohistochemical Changes in the Liver}

Figures $(4 \mathrm{~A}, 4 \mathrm{~F})$ illustrate the identification and distribution of p53 immunoreactivity (p53-ir) in liver tissues for all studied groups. The hepatic immunohistochemical examinations in the control and 
damiana groups display weak p53-ir in the rat hepatocytes (Fig. 4A, 4B). While, a heavy positive reaction for $\mathrm{p} 53$-ir was spotted in the hepatic sections of rats exposed to AMI alone and with self -healing (Fig. 4C, 4D). In contrast, the density of p53-ir showed a mild to moderate improvement of hepatocytes in the co-treated group (Fig. 4E). In the same context, moderate positive reactivity for p53-ir was detected in the liver sections of rats in the post-treated group (Fig. 4F).

\section{PCNA Immunohistochemical Changes in the Liver}

The hepatic immunohistochemical examination of PCNA-ir for all treated groups is presented in (Fig. 5A-5F).
The hepatic sections of rats in the control and damiana groups revealed a faint expression for PCNA-ir in the nuclei of hepatocytes (Fig. 5A, 5B). A severe or strong reactivity for PCNA-ir were illustrate in rats liver tissues which treatment with AMI alone or by self -healing groups as compare with the control and damiana groups (Fig. 5C, 5D).

Furthermore, a moderate positive repression for PCNA-ir were detected in the nuclei of hepatocytes of co-treated group (Fig. 5E). Also, the sections of liver in post- treated group showed mild to moderate positive reactions for PCNA-ir in hepatocytes when compare to the AMI group (Fig. 5F).

Table 1: Changes in serum liver functions (ALT, AST, ALP, albumin and total protein) in different groups

\begin{tabular}{llllll}
\hline Groups & ALT $(\mathrm{U} / \mathrm{I})$ & AST $(\mathrm{U} / \mathrm{I})$ & ALP $(\mathrm{U} / \mathrm{I})$ & Albumin $(\mathrm{g} / \mathrm{dl})$ & Total protein $(\mathrm{g} / \mathrm{dl})$ \\
\hline Control & $46.2^{\#} \pm 4.50$ & $154.6^{\#} \pm 4.37$ & $147.2^{\#} \pm 3.02$ & $3.07^{\#} \pm 0.03$ & $7.01^{\#} \pm 0.07$ \\
Damiana & $41.6^{\#} \pm 1.99$ & $141.4^{\#} \pm 2.50$ & $140^{\#} \pm 0.44$ & $3.08^{\#} \pm 0.06$ & $6.90^{\#} \pm 0.03$ \\
AMI & $83^{*} \pm 2.15$ & $271.4^{*} \pm 5.11$ & $193^{*} \pm 4.64$ & $2.37^{*} \pm 0.09$ & $5.33^{*} \pm 0.06$ \\
Co-treated & $58^{\# * \pm 1.82}$ & $219^{\# *} \pm 4.15$ & $147.6^{\#} \pm 3.44$ & $2.88^{\#} \pm 0.06$ & $6.18^{\# * \pm 0.065}$ \\
Post treated & $58.2^{\# * \pm 1.99}$ & $246^{\# * \pm 3.03}$ & $169^{\# * \pm 3.56}$ & $2.80^{\# * \pm 0.04}$ & $6.38^{\# * \pm 0.06}$ \\
Self treated & $65.6^{\# *} \pm 2.66$ & $266.6^{*} \pm 4.39$ & $175.4^{\# * \pm 2.11}$ & $2.50^{*} \pm 0.04$ & $5.76^{*} \pm 0.07$ \\
\hline
\end{tabular}

Data are expressed as mean \pm S.E of 10 observations. Significant difference from all studied groups at $P<0.05$. \# and *respectively denote difference of significance from AMI and from control

Table 2: Comet assay parameters in the liver obtained by image analysis in cells of all groups after the treatment experiment

\begin{tabular}{lrlllr}
\hline Groups & Tailed \% & Untailed \% & Tails length $\mu \mathrm{m}$ & Tail DNA\% & Tail moment \\
\hline Control & 2.0 & 98.0 & $1.46 \pm 0.11^{\mathrm{d}}$ & 1.53 & 2.23 \\
Damiana & 2.5 & 97.5 & $1.50 \pm 0.10^{\mathrm{d}}$ & 1.58 & 2.37 \\
AMI & 25.5 & 74.5 & $9.20 \pm 0.43^{\mathrm{a}}$ & 6.01 & 55.29 \\
Co-treated & 6.0 & 94.0 & $3.02 \pm 0.11^{\mathrm{c}}$ & 2.26 & 6.83 \\
Post treated & 12.0 & 88.0 & $4.77 \pm 0.22^{\mathrm{b}}$ & 3.74 & 17.84 \\
Self treated & 15.5 & 84.5 & $3.11 \pm 0.13^{\mathrm{c}}$ & 2.39 & 7.43 \\
\hline
\end{tabular}

Values are expressed as mean \pm SEM; Values carrying different superscript letters in the same row were significantly different at $\mathrm{p}<0.05$

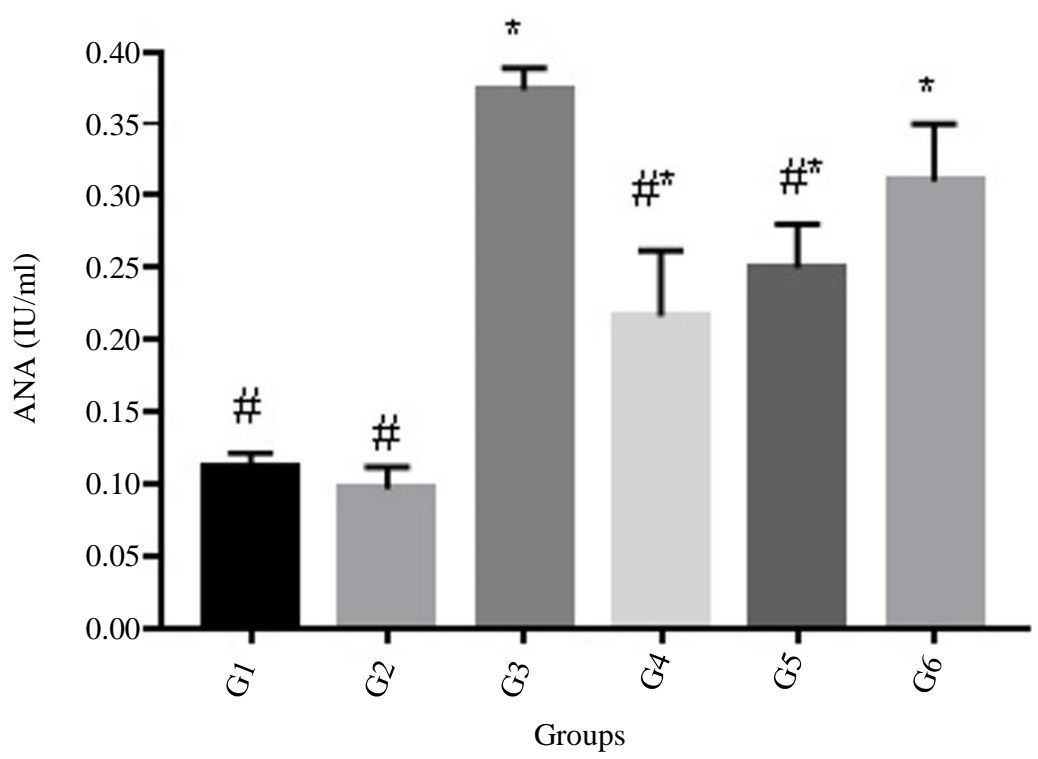

Fig. 1: Changes in serum ANA levels in different groups. Where G1, control; G2, damiana; G3, AMI; G4, co- treated; G5, posttreated; G6, self -treated AMI. \# and *respectively denote difference of significance from G3 and from G1 

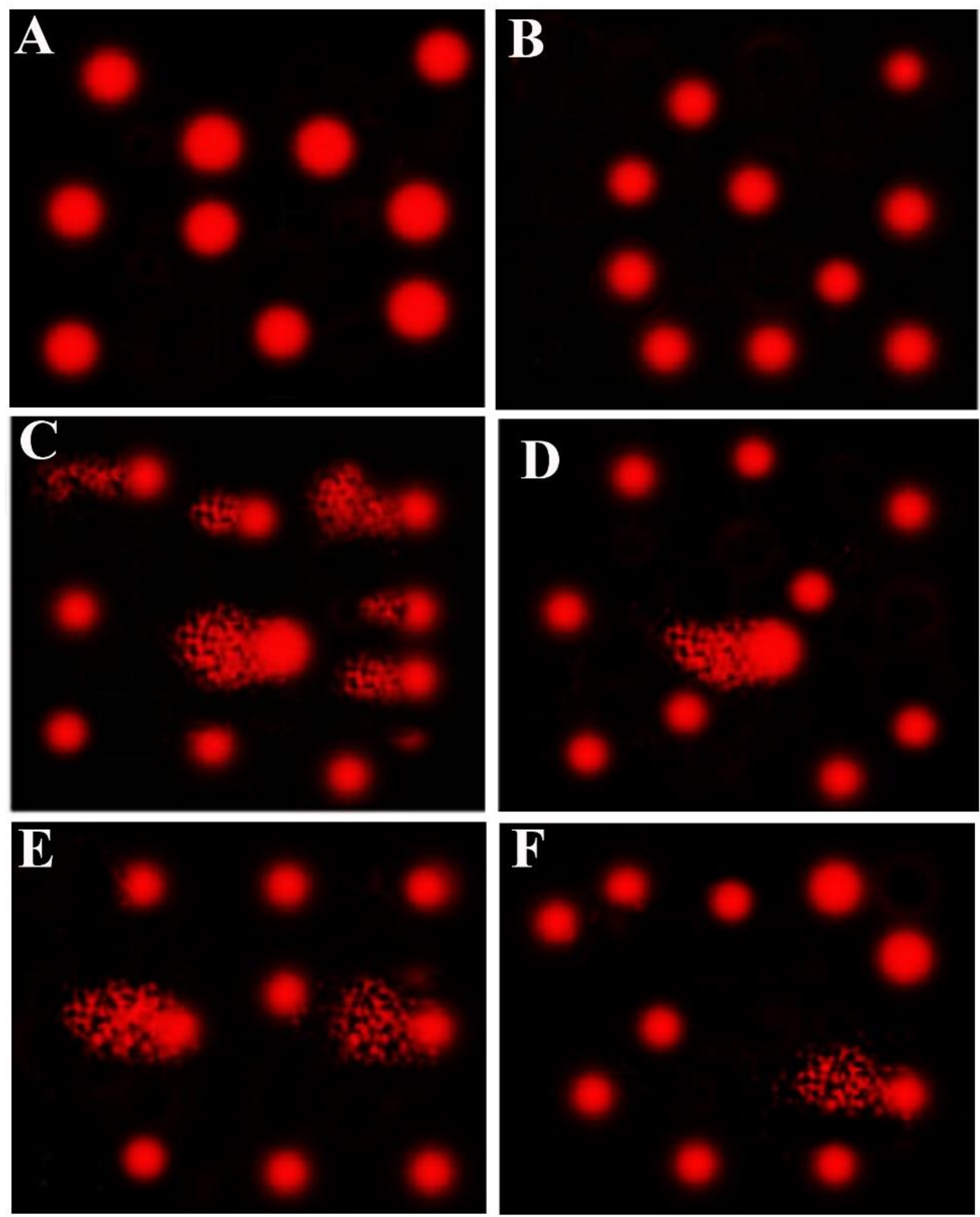

Fig. 2: Photomicrographs representation of DNA damage in liver tissues using comet assay, (Control group, A; damiana group, B; amitriptyline group, C; co-treated group, D; post-treated group, E; self-cured group, E) 

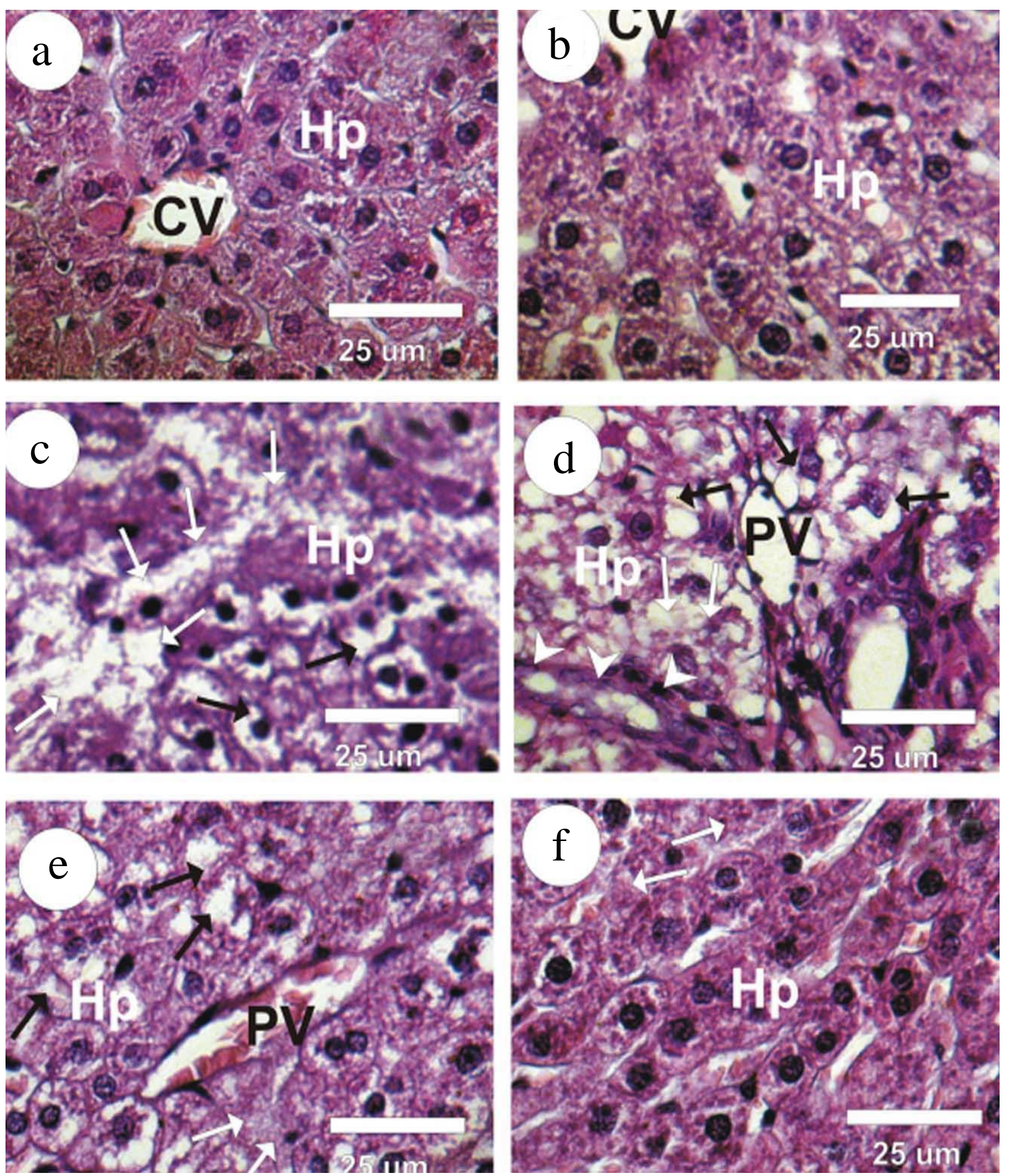

Fig. 3: Photomicrographs of rat's liver sections in the different groups. A\&B: Liver sections in control (G1) and damiana (G2) groups revealed the normal structure of Hepatocytes $(\mathrm{Hp})$ with normal central veins $(\mathrm{CV})$. C\&D: Liver sections in amitriptyline (G3) and self-recovered (G6) groups showed a disturbance of the hepatocyte's radially arranged cords, marked hepatocellular vacuolations, cytoplasmic vacuolation, moderate fibrosis and marked diffuse necrosis of hepatic tissue. E: Liver sections in cotreated amitriptyline with damiana (G4) revealed moderate vacuolated hepatocytes and congestion in portal veins. F: Liver sections in post-treated amitriptyline with damiana (G5) revealed the normal structure of hepatocytes 

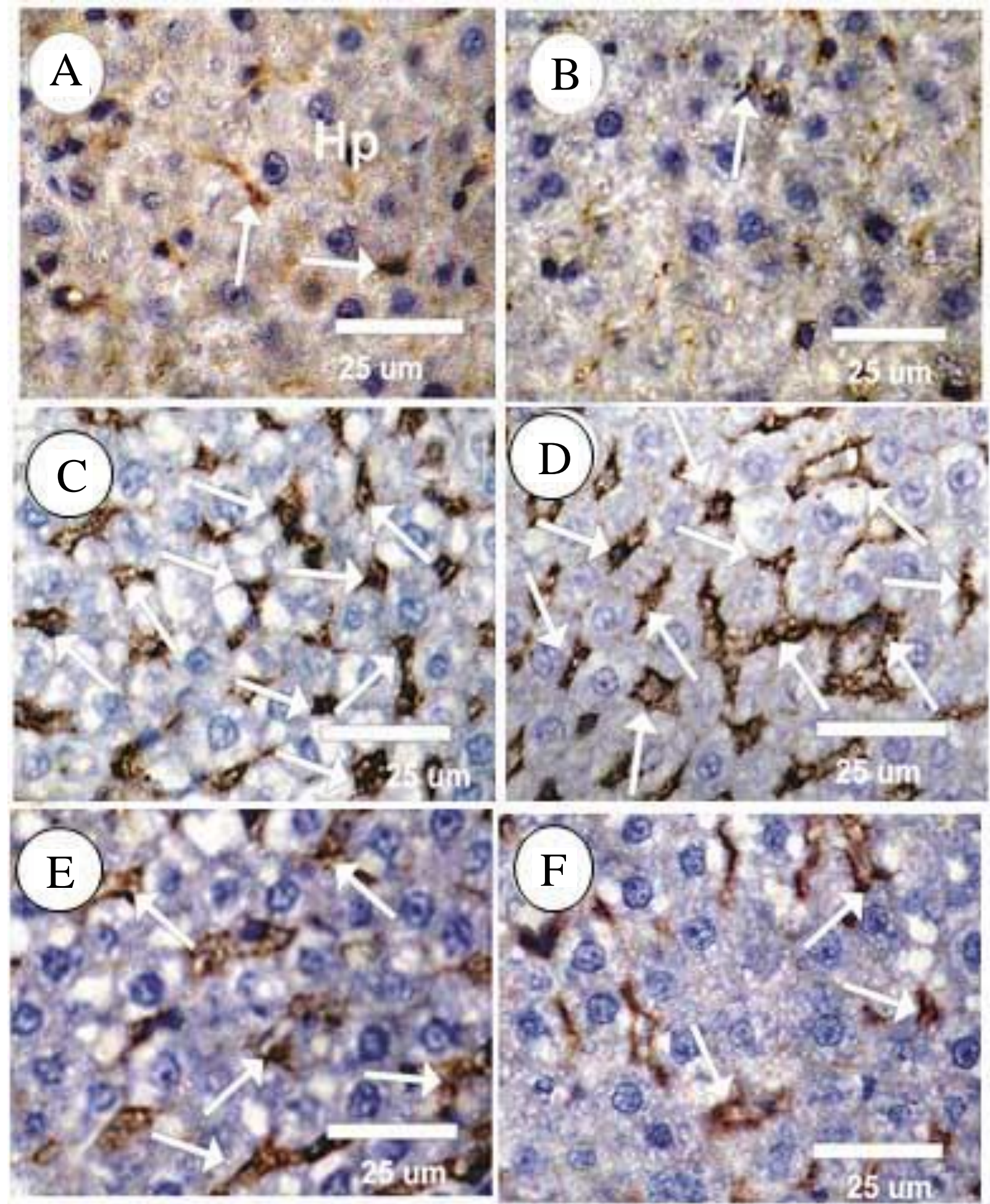

Fig. 4: Photomicrograph of apoptotic p53 immunoreactivity (p53-ir) in different groups. A\&B: Faint positive reaction for P53-ir was detected in the hepatocytes in the control (G1) and damiana (G2) groups. C\&D: Strong positive reactions for p53-ir were detected in the liver cytoplasm in treated rats with amitriptyline (G3) and amitriptyline self-recovered (G6) groups. E: Moderate positive reactions for p53-ir were detected in the cytoplasm in co-treated amitriptyline with the damiana (G4) group. F: Liver sections in post-treated amitriptyline with the damiana (G5) group revealed mild to moderate positive reactions were detected for P53-ir in the liver cytoplasm 

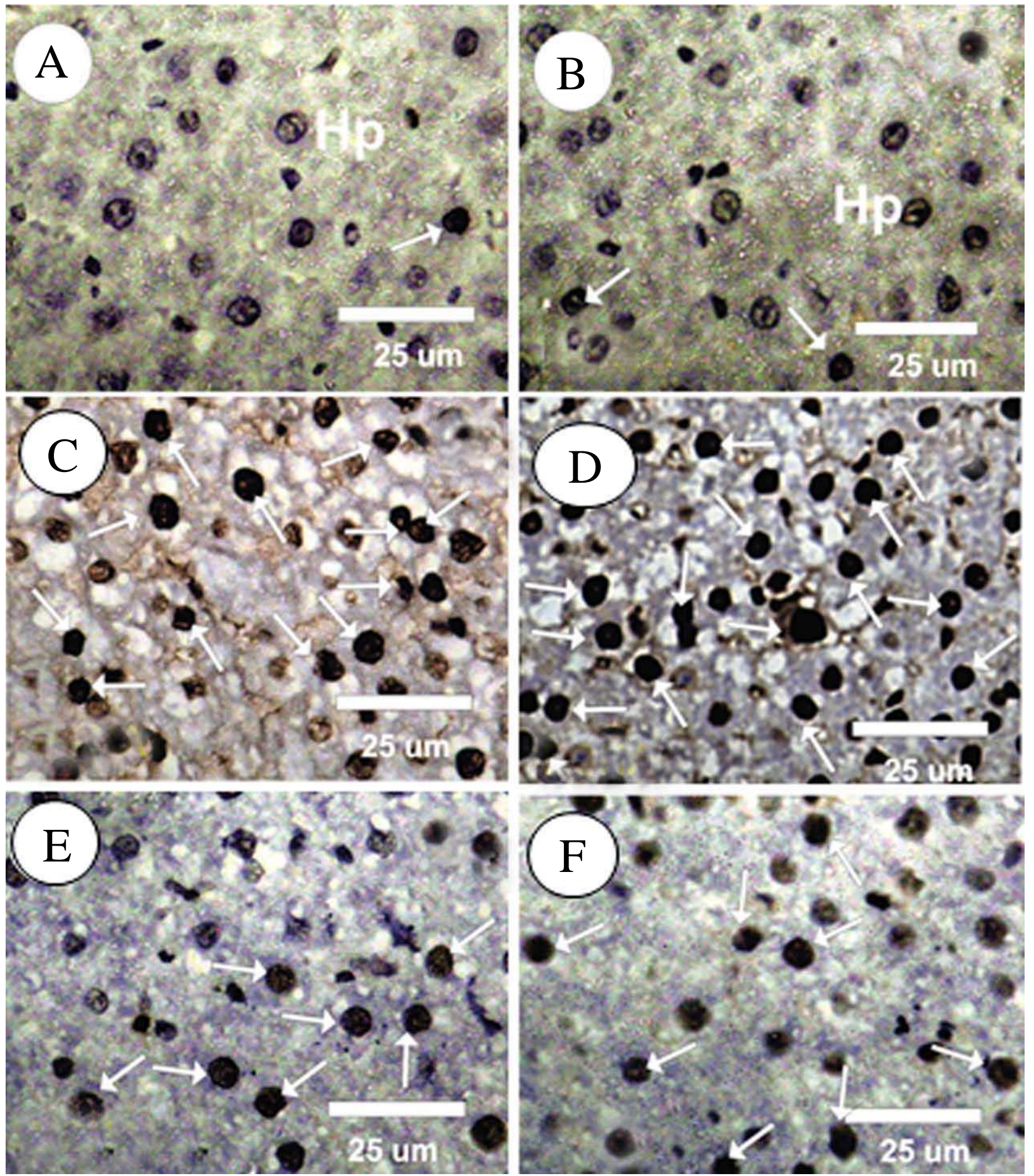

Fig. 5: Photomicrograph of rat liver section of PCNA immunoreactivity in different groups. A\&B: Faint positive reaction for PCNAir were identified in the hepatocytes in the control (G1) and damiana (G2) groups. C\&D Strong positive reactions (grade 5) for PCNA-ir were noticed in the hepatocytes in treated rats with amitriptyline (G3) and amitriptyline self-recovered (G6) groups. E: Moderate positive reactions for PCNA-ir were noticed on the hepatocytes in co-treated amitriptyline with the damiana (G4) group. F: Liver sections in post-treated amitriptyline with the damiana (G5) group shown mild to moderate positive reactions for PCNA-ir in the hepatocytes nuclei 


\section{Discussion}

Despite the quantity of reports demonstrating the results related with amitriptyline, it is still broadly used to treat melancholy and diminish the seriousness of mental issues and ongoing nerve torment (Goldman et al., 2010; Kalita et al., 2014), the liver is one of the fundamental organs that are defenseless against the poisonous impacts of these medications due to its parts in utilizing drugs and control different physiological cycles. As of late, there is extraordinary premium in utilizing restorative plants and spices for the avoidance and treatment of numerous infections (Almakhatreh et al., 2020; Mutar and Tousson, 2020) from this viewpoint, the flow research expected to contemplate the defensive job of damiana separate on rodents administrated with amitriptyline through assessment of the advancements that are going on liver compounds and proteins in serum just as observing the progressions in the DNA harm, histological and immunohistochemical assessments in hepatic tissues.

The outcomes acquired through our investigation showed the defensive impact of damiana separate, where the level of every one of the liver compounds, all out protein and, egg whites that were concentrated in the prophylactic gathering and which were treated with damiana remove and amitriptyline together were near their level in the ordinary gathering, which affirms the preventive significance of damiana. Likewise, the portions utilized were protected and didn't have any destructive poisonous impacts.

Round $15 \%$ of these therapies effectsly affect chemical levels and is target organs like liver and kidney with significant natural and clinical ramifications, which help our body in separating and eliminated drugs, including antidepressants. Consequently, in the current past, a few pharmacological researches have been centered around the impacts of cell reinforcements in various neurotic settings (Obianime et al., 2010; Khan et al., 2010). Different adjuvant mixtures have been pushed for alleviating hepatic and renal dysfunctions related with energizer drug treatment, however moderately couple of mixtures have been exposed to serious assessment. In boundless medication, Turnera diffusa or damiana of the family Turneraceae is cautious as a Spanish fly (Estrada-Reyes et al., 2009)

Phytochemical contemplates have recognized that Turners diffusa contains different constituents like flavonoids, alkaloids, tannins and phenolic intensifies that can diminish liver harm on account of its cell reinforcement attributes (Piacente et al., 2002; Hung et al., 2006; Bernardo et al., 2017). Subsequently, this examination expects to explore the remedial and defensive job of damiana remove aginst amitriptyline initiated harmfulness, immune system problems, DNA harm, injury, apoptosis and expansion adjustments in liver tissues.
The liver assumes a crucial part in controlling numerous physiological cycles as it attempts to separate or change harmful substances and use drugs. Numerous prescriptions can influence the way the liver works, cause harm to it, or do both and a few medications, like antidepressants, can expand levels of liver proteins (AST and ALT) and cause liver harm (typically minor harm), however without manifestations (Tortora and Grabowski, 2002). Liver chemicals are proteins that are emitted from the liver in limited quantities in the ordinary way, which assists with speeding up fundamental cycles in the body and convert food into energy. Our examination showed that treatment with amitriptyline in the third gathering prompts weakened liver capacity through an increment in the degree of liver compounds (ALT, AST and ALP) in the serum just as a lessening in the degrees of both absolute protein and egg whites. Moreover, our outcomes were reliable with a few examinations that showed the amitriptyline actuated poisonousness and injury in the liver and these outcomes concurred with Afify et al. (2010; Vuppalanchi et al., 2010; Voican et al., 2014) who revealed that the amitriptyline instigated checked degenerations and provocative cell invasion in liver tissues just as it builds the serum liver catalysts movement (AST, ALT, ALP and $\gamma \mathrm{GT}$ ) in the male rodents. Additionally, DeSanty and Amabile (2007) exhibited that the tricyclic and tetracyclic antidepressants can prompt harm and poisonousness in the liver, particularly in patients with polypharmacy paying little heed to the portion.

Kotta et al. (2013) announced that investigation of damiana with HPLC, GC-MS assessment showed the presence of caffeine, arbutine and flavonoids as the fundamental mixtures in the dynamic concentrate. The outcomes upheld the utilization of damiana utilized as a love potion in conventional medication and recommend conceivable helpful properties of damiana on liver dysfunctions. Be that as it may, the serum ALT, AST and ALP levels were a critical decrease in amitriptyline treated with damiana (co and post) bunches when contrasted and Amitriptyline and self-treated amitriptyline gatherings. ALT, AST and ALP levels were a critical decrease in co-treated amitriptyline with damiana bunch when contrasted and post-treated amitriptyline with damiana bunch. Our outcomes show that egg whites and absolute protein levels in amitriptyline treated with damiana (co and post) were an irrelevant increment when contrasted and amitriptyline and selftreated amitriptyline gatherings. Albumin and total protein levels were the irrelevant expansion in co-treated amitriptyline with the damiana when contrasted and posttreated amitriptyline with the damiana bunch.

Amitriptyline instigates oxidative stress and lipid peroxidation in the numerous organs like liver, kidney, mind and heart relying upon the measure of portion utilized and the individual's medical issue. Moreover, the 
liver and lung more showcase to amitriptyline poisonousness (Bautista-Ferrufino et al., 2011). Besides, there are a few phytochemicals and normal items which contain cancer prevention agents and against aggravation that can lessen the hurtful impacts of free extremists or tumor-silencer qualities and can actuating apoptosis in harmed cells (Abd Eldaim et al., 2019; Mutar et al., 2020). Notwithstanding, amitriptyline instigates DNA harm in the liver tissue that was seen in the comet measure in the third gathering, which showed the tallness of the tail length, tail DNA \% and tail second as contrasted and the benchmark group. Despite what is generally expected, the presence of damiana in co-treated, post-treated, selfrelieved prompted a decrease in the harm to the liver tissue contrasted with the amitriptyline bunch.

There are numerous makes that lead the event of immune system illnesses like drinking liquor, infections, some metabolic issues and when ingesting certain medications, yet there is no unmistakable reason for resistant hepatitis. Hostile to ANA assessment isn't explicit to a specific illness, yet it's anything but a valuable test for the underlying discovery of an immunological issue all in all and it is exhaustive for some safe sicknesses (Miyachi et al., 2003; Beretta-Piccoli et al., 2020). In our examination, we needed to know the cautious invulnerability job performed by the counter ANA against the poisonousness of antidepressants; just as the job of damiana in the defensive and restorative of immune system liver sickness in serum rodents. Thus, the contemplated bunches showed a huge expansion in serum ANA levels in the amitriptyline bunch when contrasted and control and damiana gatherings while an immaterial lessening in ANA levels in amitriptyline bunch when contrasted and self-treated amitriptyline bunch. Then again; treatment of amitriptyline treated with damiana (co or post) bunches uncovered a critical reduction when contrasted and the amitriptyline bunch. A critical decline in serum ANA levels was distinguished in co-treated amitriptyline with the damiana bunch when contrasted and post-treated amitriptyline with the damiana.

Histological assessment showed that the amitriptyline incited striking degeneration by confusions of the hepatic lines, additionally to pyknotic cores demonstrating apoptosis and irritation in liver cells. Our information concur with Garcia-Pando et al. (2002; Breyer-Pfaff, 2004; Ferrajolo et al., 2018) who showed that the organization of sertraline, clozapine, amitriptyline and imipramine drugs instigate lift the liver compound levels (AST and ALT) in the serum and hepatic harm in tissues. Likewise, a few examinations have demonstrated poisonousness and injury in the liver tissue brought about by antidepressants, particularly amitriptyline so it can forestall the assimilation of Noradrenaline (NA) and 5-Hydroxytryptamine (5-HT) because of its processed into pamelor (nortriptyline $\mathrm{HCl}$ ) (Buratti and Lavine, 2002;
Al-Attar and Abu Zeid, 2013; Pladevall-Vila et al., 2019). In any case, the hepatic tissue in the amitriptyline selfrecuperated bunch didn't show any enhancement in the liver construction. while the organization with damiana in the cotreated and present treated gatherings leads on upgrade in the focal and entry veins in the liver tissue. The upgrade was more articulated in a post-treated gathering.

The immunoreactivity articulation for multiplying cell atomic antigen (PCNA-ir) and P53-ir showed a solid positive response for PCNA-ir and P53 immunoreactivity in the hepatocytes in treated rodents with amitriptyline and amitriptyline self-recuperated bunches when contrasted and control and damiana gatherings. While, our outcomes showed moderate to gentle positive responses for PCNA-ir and P53-ir on the hepatocytes in the co-treated and post-treated gatherings individually when contrasted with treated rodents with amitriptyline.

Besides, various examinations have uncovered the advantages of damiana against numerous sicknesses, Taha et al. (2012) tracked down that the Turnera diffusa has against ulcer action, which could adjust the lipid peroxidation, immunomodulatory and hostile to oxidant components just as balancing the degrees of interleukin-6, interleukin-10 and TNF- $\alpha$. Additionally, Kumar et al. (2008; Szewczyk and Zidorn, 2014) announced that damiana has positive exercises for soothing, against nervousness and pain relieving. Also, Estrada-Reyes et al. (2013) educated that anxiolytic-like impacts for Turnera diffusa (fluid concentrate) were assigned by a markdown in combined covering conduct. Additionally, Damiana has antioxidative properties that may forestall harm prompted by mitochondrial oxidative pressure in kidneys of Streptozotocin-actuated Diabetes Mellitus (STZ-DM) rodents (Edgar Romualdo et al., 2018).

Besides, Estrada-Reyes et al. (2009) revealed that Turnera diffusa recuperates sexual conduct in physically depleted (SExh) male rodents and to recognize the principle parts in a watery concentrate. Notwithstanding, Turnera diffusa is enormously perceived for its therapeutic properties for the treatment of a few sicknesses, for example, kidney issues and diabetes (Kumar et al., 2008). Additionally, Zhao et al. (2007) exhibited that Turnera diffuse in the phytochemical examination identifies the presence of cancer prevention agent compounds.

Likewise, Neven et al. (2012) revealed that damiana effectsly affected the cell reinforcement status of the analyzed rodent minds as exhibited by the expansion of SOD and GPx exercises in cerebrum tissues and it diminishes MDA and expanded GSH levels in the rodent serum.

\section{Conclusion}

Our outcomes demonstrate that amitriptyline actuates liver harmfulness, immune system issues, DNA damage, injury and proliferation alterations in rats. Administration 
with damiana modulates liver enzymes, ameliorate liver DNA damage, enhanced Autoimmune (ANA) disorders, improved liver histopathological and immunohistochemical examinations (p53 and PCNA). Moreover, the beneficial effects of damiana might a prominent role in promoting clinically strategies to treat patients with amitriptylineinduced liver damage.

\section{Author's Contributions}

Ahmed F. Hasan, Thulfiqar F. Mutar and Ehab Tousson: Wrote the first draft of the manuscript, managed the literature searches and the analyses of the study.

Shatha Ghazi Felemban: Designed the study, performed the statistical analysis, wrote the protocol.

\section{Ethics}

This article is original and contains unpublished material. The corresponding author confirms that have read and approved the manuscript and no ethical issues involved.

\section{References}

Abd Eldaim, M. A., Tousson, E., El Sayed, I. E. T., \& Awd, W. M. (2019). Ameliorative effects of Saussurea lappa root aqueous extract against Ethephon-induced reproductive toxicity in male rats. Environmental Toxicology, 34(2), 150-159. https://doi.org/10.1002/tox.22669

Abd Eldaim, M. A., Tousson, E., El Sayed, I. E. T., Abd Elmaksoud, A. Z., \& Ahmed, A. A. (2021). Ameliorative effects of 9-diaminoacridine derivative against Ehrlich ascites carcinoma-induced hepatorenal injury in mice. Environmental Science and Pollution Research, 28(17), 21835-21850. https://doi.org/10.1007/s11356-020-11857-y

Abd, H. H., Ahmed, H. A., \& Mutar, T. F. (2020). Moringa oleifera leaves extract modulates toxicity, sperms alterations, oxidative stress and testicular damage induced by tramadol in male rats. Toxicology Research, 9(2), 101-106. https://doi.org/10.1093/toxres/tfaa009

Afify, M., Abd Elmaksoud, M. D. E., Mosa, T., Elshaer, M., \& Kotb, N. (2010). Differential effects of amitriptyline treatment on testicular and liver functions in adult male rats. New York Science Journa, 3(3).

Al-Attar, A. M., \& Abu Zeid, I. M. (2013). Effect of tea (Camellia sinensis) and olive (Olea europaea L.) leaves extracts on male mice exposed to diazinon. BioMed Research International, 2013, 1-6. https://doi.org/10.1155/2013/461415

Alcaraz-Melendez, L., Real-Cosio, S., Suchý, V., \& Švajdlenka, E. (2007). Differences in essential oil production and leaf structure in pheno-types of damiana (turnera diffusa willd. Journal of Plant Biology, 50(3), 378-382. https://doi.org/10.1007/BF03030671
Aldubayan, M. A., Elgharabawy, R. M., Ahmed, A. S., \& Tousson, E. (2019). Antineoplastic activity and curative role of avenanthramides against the growth of ehrlich solid tumors in mice. Oxidative Medicine and Cellular Longevity, 2019. https://doi.org/10.1155/2019/5162687

Almakhatreh, M., Mutar, T. F., \& Tousson, E. (2020). Therapeutic Role of Rosemary Extract against Vepesid Induced Kidney Injury, Proliferation and Apoptosis in Male Rats. Asian Oncology Research Journal, 16-25. https://www.journalaorj.com/index.php/AORJ/article /view/30113

Alotaibi, B., El-Masry, T. A., Tousson, E., Alarfaj, S. J., \& Saleh, A. (2020). Therapeutic effect of rocket seeds (Eruca sativa L.) against hydroxyapatite nanoparticles injection induced cardiac toxicity in rats. Pakistan Journal Pharmacy Science, 33(4), 1839-1845.

Alotaibi, B., Tousson, E., El-Masry, T. A., Altwaijry, N., \& Saleh, A. (2021). Ehrlich ascites carcinoma as model for studying the cardiac protective effects of curcumin nanoparticles against cardiac damage in female mice. Environmental Toxicology, 36(1), 105-113. https://doi.org/10.1002/tox.23016

Al-Rasheed, N. M., El-Masry, T. A., Tousson, E., Hassan, H. M., \& Al-Ghadeer, A. (2018). Hepatic protective effect of grape seed proanthocyanidin extract against Gleevec-induced apoptosis, liver Injury and Ki67 alterations in rats. Brazilian Journal of Pharmaceutical Sciences, 54(2). https://doi.org/10.1590/s2175-97902018000217391

Altwaijry, N., El-Masry, T. A., Alotaibi, B. S., Tousson, E., Alodhayani, A. A., El-Morshedy, K., ... \& Saleh, A. (2021). Potential therapeutic effects of avenanthramide-C against lung toxicity caused by silver nanoparticles injection in rats. Pakistan Journal Pharmacy Science, 34(1), 337-343.

Altwaijry, N., El-Masry, T. A., Alotaibi, B., Tousson, E., \& Saleh, A. (2020). Therapeutic effects of rocket seeds (Eruca sativa L.) against testicular toxicity and oxidative stress caused by silver nanoparticles injection in rats. Environmental Toxicology, 35(9), 952-960. https://doi.org/10.1002/tox.22931

Bae, S. K., Yang, K. H., Aryal, D. K., Kim, Y. G., \& Lee, M. G. (2009). Pharmacokinetics of amitriptyline and one of its metabolites, nortriptyline, in rats: Little contribution of considerable hepatic first-pass effect to low bioavailability of amitriptyline due to great intestinal first-pass effect. Journal of Pharmaceutical Sciences, 98(4), 1587-1601. https://doi.org/10.1002/jps.21511

Basol, N., Aygun, H., \& Gul, S. S. (2019). Beneficial effects of edaravone in experimental model of amitriptylineinduced cardiotoxicity in rats. Naunyn-Schmiedeberg's Archives of Pharmacology, 392(11), 1447-1453. https://doi.org/10.1007/s00210-019-01683-6 
Bautista-Ferrufino, M. R., Cordero, M. D., Sánchez-Alcázar, J. A., Illanes, M., Fernández-Rodríguez, A., Navas, P., \& de Miguel, M. (2011). Amitriptyline induces coenzyme Q deficiency and oxidative damage in mouse lung and liver. Toxicology Letters, 204(1), 32-37. https://doi.org/10.1016/j.toxlet.2011.03.033

Belfield, A., \& Goldberg, D. (1971). Colorimetric determination of alkaline phosphatase activity. Enzyme, 12(5), 561-568. https://doi.org/10.1159/000459586

Beretta-Piccoli, B. T., Mieli-Vergani, G., \& Vergani, D. (2020). Autoantibodies and Understanding of Autoimmune Liver Diseases. Autoimmune Liver Disease: Management and Clinical Practice, 65-82. https://doi.org/10.1002/9781119532637.ch4

Bernardo, J., Ferreres, F., Gil-Izquierdo, Á., Valentao, P., \& Andrade, P. B. (2017). Medicinal species as MTDLs: Turnera diffusa Willd. Ex Schult inhibits CNS enzymes and delays glutamate excitotoxicity in SH-SY5Y cells via oxidative damage. Food and Chemical Toxicology, 106, 466-476. https://doi.org/10.1016/j.fct.2017.06.014

Bowers, L. D., \& Wong, E. T. (1980). Kinetic serum creatinine assays. II. A critical evaluation and review. Clinical Chemistry, 26(5), 555-561. https://doi.org/10.1093/clinchem/26.5.0555

Breyer-Pfaff, U. (2004). The metabolic fate of amitriptyline, nortriptyline and amitriptylinoxide in man. Drug Metabolism Reviews, 36(3-4), 723-746. https://doi.org/10.1081/DMR-200033482

Buratti, S., \& Lavine, J. E. (2002). Drugs and the liver: advances in metabolism, toxicity and therapeutics. Current Opinion in Pediatrics, 14(5), 601-607. https://doi.org/10.1097/00008480-200210000-00007

DeSanty, K. P., \& Amabile, C. M. (2007). Antidepressant-lnduced Liver Injury. Annals of Pharmacotherapy, 41(7-8), 1201-1211. https://doi.org/10.1345/aph.1K114

Doumas, B. T., Watson, W. A., \& Biggs, H. G. (1997). Albumin standards and the measurement of serum albumin with bromcresol green. Clinical Chemical Acta, 258(1), 21-30. https://doi.org/10.1016/S00098981(96)06447-9

Edgar Romualdo, E. G., Lilia, A. M., Rafael, S. G., \& Alfredo, S. M. (2018). Antioxidant effects of damiana (Turnera diffusa Willd. ex Schult.) in kidney mitochondria from streptozotocin-diabetic rats. Natural Product Research, 32(23), 2840-2843. https://doi.org/10.1080/14786419.2017.1380009

El-Masry, T. A., Al-Shaalan, N. H., Tousson, E., Buabeid, M., \& Alyousef, A. M. (2019). The therapeutic and antineoplastic effects of vitamin B17 against the growth of solid-form Ehrlich tumours and the associated changes in oxidative stress, DNA damage, apoptosis and proliferation in mice. Pakistan Journal Pharmacy Science, 32(6), 2801-2810.
El-Masry, T. A., Altwaijry, N., Alotaibi, B., Tousson, E., Alboghdadly, A., \& Saleh, A. (2020). Chicory (Cichorium intybus L.) extract ameliorates hydroxyapatite nanoparticles induced kidney damage in rats. Pakistan Journal Pharmacy Science, 33(3), 1251-1260.

Estrada-Reyes, R., Carro-Juárez, M., \& Martínez-Mota, L. (2013). Pro-sexual effects of Turnera diffusa Wild (Turneraceae) in male rats involves the nitric oxide pathway. Journal of Ethnopharmacology, 146(1), 164-172. https://doi.org/10.1016/j.jep.2012.12.025

Estrada-Reyes, R., Ferreyra-Cruz, O. A., Jiménez-Rubio, G., Hernández-Hernández, O. T., \& Martínez-Mota, L. (2016). Prosexual effect of Chrysactinia mexicana A. Gray (Asteraceae), False damiana, in a model of male sexual behavior. BioMed Research International, 2016, 1-9. https://doi.org/10.1155/2016/2987917

Estrada-Reyes, R., Ortiz-López, P., Gutiérrez-Ortíz, J., \& Martínez-Mota, L. (2009). Turnera diffusa Wild (Turneraceae) recovers sexual behavior in sexually exhausted males. Journal of Ethnopharmacology, 123(3), 423-429. https://doi.org/10.1016/j.jep.2009.03.032

Ferrajolo, C., Scavone, C., Donati, M., Bortolami, O., Stoppa, G., Motola, D., ... \& Capuano, A. (2018). Antidepressant-induced acute liver injury: a casecontrol study in an Italian inpatient population. Drug Safety, 41(1), 95-102. https://doi.org/10.1007/s40264017-0583-5

Garcia-Pando, A. C., del Pozo, J. G., Sanchez, A. S., Martin, A. V., \& Lucena, M. I. (2002). Hepatotoxicity associated with the new antidepressants. The Journal of Clinical Psychiatry, 63(2), 135-137. https://doi.org/10.4088/JCP.v63n0208

Garza-Juárez, A., de la Luz Salazar-Cavazos, M., SalazarAranda, R., Pérez-Meseguer, J., \& de Torres, N. W. (2011). Correlation between chromatographic fingerprint and antioxidant activity of Turnera diffusa (Damiana). Planta Medica, 77(09), 958-963. https://doi.org/10.1055/s-0030-1250684

Goldman, R. H., Stason, W. B., Park, S. K., Kim, R., Mudgal, S., Davis, R. B., \& Kaptchuk, T. J. (2010). Low-dose amitriptyline for treatment of persistent arm pain due to repetitive use. PAIN@, 149(1), 117-123. https://doi.org/10.1016/j.pain.2010.01.016

Hassanane, M. S., Hafiz, N., Radwan, W., \& El-Ghor, A. A. (2012). Genotoxic evaluation for the tricyclic antidepressant drug, amitriptyline. Drug and Chemical Toxicology, 35(4), 450-455. https://doi.org/10.3109/01480545.2011.642382

Häuser, W., Petzke, F., Üçeyler, N., \& Sommer, C. (2011). Comparative efficacy and acceptability of amitriptyline, duloxetine and milnacipran in fibromyalgia syndrome: a systematic review with meta-analysis. Rheumatology, 50(3), 532-543. https://doi.org/10.1093/rheumatology/keq354 
Hung, M. Y., Fu, T. Y. C., Shih, P. H., Lee, C. P., \& Yen, G. C. (2006). Du-Zhong (Eucommia ulmoides Oliv.) leaves inhibits $\mathrm{CCl} 4$-induced hepatic damage in rats. Food and Chemical Toxicology, 44(8), 1424-1431. https://doi.org/10.1016/j.fct.2006.03.009

Kalita, J., Kohat, A. K., Misra, U. K., \& Bhoi, S. K. (2014). An open labeled randomized controlled trial of pregabalin versus amitriptyline in chronic low backache. Journal of the Neurological Sciences, 342(12), 127-132. https://doi.org/10.1016/j.jns.2014.05.002

Khan, A., Bhat, A., Kolts, R., Thase, M. E., \& Brown, W. (2010). Why has the antidepressant-placebo difference in antidepressant clinical trials diminished over the past three decades?. CNS neuroscience and Therapeutics, 16(4), 217-226. https://doi.org/10.1111/j.1755-5949.2010.00151.x

Kotta, S., Ansari, S. H., \& Ali, J. (2013). Exploring scientifically proven herbal aphrodisiacs. Pharmacognosy Reviews, 7(13), 1-10. https://doi.org/10.4103/0973-7847.112832

Kumar, S., Madaan, R., \& Sharma, A. (2008). Pharmacological evaluation of bioactive principle of Turnera aphrodisiaca. Indian Journal of Pharmaceutical Sciences, 70(6), 740-744. https://doi.org/10.4103/0250-474X.49095

LaLone, C. A., Hammer, K. D., Wu, L., Bae, J., Leyva, N., Liu, Y., ... \& Birt, D. F. (2007). Echinacea species and alkamides inhibit prostaglandin $\mathrm{E} 2$ production in RAW264. 7 mouse macrophage cells. Journal of Agricultural and Food Chemistry, 55(18), 7314-7322. https://doi.org/10.1021/jf063711a

Mika, J., Zychowska, M., Makuch, W., Rojewska, E., \& Przewlocka, B. (2013). Neuronal and immunological basis of action of antidepressants in chronic pain-clinical and experimental studies. Pharmacological Reports, 65(6), 1611-1621. https://doi.org/10.1016/S1734-1140(13)71522-6

Miyachi, K., Hankins, R. W., Matsushima, H., Kikuchi, F., Inomata, T., Horigome, T., ... \& Miyakawa, H. (2003). Profile and clinical significance of antinuclear envelope antibodies found in patients with primary biliary cirrhosis: a multicenter study. Journal of Autoimmunity, 20(3), 247-254. https://doi.org/10.1016/S0896-8411(03)00033-7

Mutar, T. F., \& Tousson, E. (2020). Effectivity of Some Natural Compounds against Ehrlich Tumor and Associated Diseases. Asian Oncology Research Journal, 32-41.

Mutar, T. F., Tousson, E., Hafez, E., Abo Gazia, M., \& Salem, S. B. (2020). Ameliorative effects of vitamin B17 on the kidney against Ehrlich ascites carcinoma induced renal toxicity in mice. Environmental Toxicology, 35(4), 528-537. https://doi.org/10.1002/tox.22888
Neven, M. M., Sahar, A. A., Nematalla, K. M., \& Abdelaziz, M. H. M. (2012). Comparative study between damiana and thyme on nervous system impairment during aging. New York Science Journal, 5(5), 50-61.

Obianime, A. W., Ahiwe, N. J., \& Aprioku, J. S. (2010). Effects of vitamins $\mathrm{C}$ and $\mathrm{E}$ pretreatments on cadmiuminduced serum levels of some biochemical and hormonal parameters in the female guinea pig. African Journal of Biotechnology, 9(39), 6582-6587.

PeRez-Meseguer, J., Garza-JuáRez, A., Salazar-Aranda, R., Salazar-Cavazos, M. L., dela Torre RodríGuez, Y. C., Rivas-Galindo, V., \& De Torres, N. W. (2010). Development and validation of an HPLC-DAD analytical procedure for quality control of damiana (Turnera diffusa), using an antioxidant marker isolated from the plant. Journal of AOAC International, 93(4), 1161-1168. https://doi.org/10.1093/jaoac/93.4.1161

Piacente, S., Camargo, E. E., Zampelli, A., Gracioso, J. S., Brito, A. R. S., Pizza, C., \& Vilegas, W. (2002). Flavonoids and arbutin from Turnera diffusa. Zeitschrift für Naturforschung C, 57(11-12), 983-985. https://doi.org/10.1515/znc-2002-11-1204

Pladevall-Vila, M., Pottegård, A., Schink, T., Reutfors, J., Morros, R., Poblador-Plou, B., ... \& Perez-Gutthann, S. (2019). Risk of acute liver injury in agomelatine and other antidepressant users in four European countries: a cohort and nested case-control study using automated health data sources. CNS Drugs, 33(4), 383-395. https://doi.org/10.1007/s40263-01900611-9

Reitman, S., \& Frankel, S. (1957). A colorimetric method for the determination of serum glutamic oxalacetic and glutamic pyruvic transaminases. American Journal of Clinical Pathology, 28(1), 56-63. https://doi.org/10.1093/ajcp/28.1.56

Saggu, S., Sakeran, M. I., Zidan, N., Tousson, E., Mohan, A., \& Rehman, H. (2014). Ameliorating effect of chicory (Chichorium intybus L.) fruit extract against 4-tert-octylphenol induced liver injury and oxidative stress in male rats. Food and Chemical Toxicology, 72, 138-146. https://doi.org/10.1016/j.fct.2014.06.029

Szewczyk, K., \& Zidorn, C. (2014). Ethnobotany, phytochemistry and bioactivity of the genus Turnera (Passifloraceae) with a focus on damiana-Turnera diffusa. Journal of Ethnopharmacology, 152(3), 424-443. https://doi.org/10.1016/j.jep.2014.01.019

Taha, M. M. E., Salga, M. S., Ali, H. M., Abdulla, M. A., Abdelwahab, S. I., \& Hadi, A. H. A. (2012). Gastroprotective activities of Turnera diffusa Willd. ex Schult. revisited: Role of arbutin. Journal of Ethnopharmacology, 141(1), 273-281. https://doi.org/10.1016/j.jep.2012.02.030 
Tondo, L., \& Baldessarini, R. J. (2016). Depression following mania. Molecular Psychiatry, 21(8), 990-990. https://doi.org/10.1038/mp.2016.63

Tortora, G. J., \& Grabowski, S. R. (2002). The digestive system (liver and gallbladder): Principles of anatomy and physiology. Harper Collins college publishers. New York, 24, 792-795.

Tousson, E. (2016). Histopathological alterations after a growth promoter boldenone injection in rabbits. Toxicology and Industrial Health, 32(2), 299-305. https://doi.org/10.1177/0748233713500821

Tousson, E., Ali, E. M., Ibrahim, W., \& Ashraf, R. M. (2012). Histopathological and immunohistochemical alterations in rat heart after thyroidectomy and the role of hemin and ketoconazole in treatment. Biomedicine and Pharmacotherapy, 66(8), 627-632. https://doi.org/10.1016/j.biopha.2012.08.009

Tousson, E., Ali, E. M., Ibrahim, W., \& Mansour, M. A. (2011). Proliferating cell nuclear antigen as a molecular biomarker for spermatogenesis in PTU-induced hypothyroidism of rats. Reproductive Sciences, 18(7), 679-686. https://doi.org/10.1177/1933719110395401

Tousson, E., Bayomy, M. F., \& Ahmed, A. A. (2018). Rosemary extract modulates fertility potential, DNA fragmentation, injury, KI67 and P53 alterations induced by etoposide in rat testes. Biomedicine and Pharmacotherapy, 98, 769-774. https://doi.org/10.1016/j.biopha.2018.01.025

Tousson, E., El-Atrsh, A., Mansour, M., \& Abdallah, A. (2019). Modulatory effects of Saussurea lappa root aqueous extract against ethephon-induced kidney toxicity in male rats. Environmental Toxicology, 34(12), 1277-1284. https://doi.org/10.1002/tox.22828

Tousson, E., Hafez, E., Gazia, MM., Salem, SB., \& Mutar, TF. (2020b). Hepatic ameliorative role of vitamin B17 against Ehrlich ascites carcinomainduced liver toxicity. Environmental Science and Pollution Research, 27, 9236-9246. https://doi.org/10.1007/s11356-019-06528-6
Tousson, E., Hafez, E., Zaki, S., \& Gad, A. (2016). The cardioprotective effects of L-carnitine on rat cardiac injury, apoptosis and oxidative stress caused by amethopterin. Environmental Science and Pollution Research, 23(20), 20600-20608. https://doi.org/10.1007/s11356-016-7220-1

Tousson, E., Hafez, E., Zaki, S., Gad, A., \& Elgharabawy, R. M. (2020a). Evaluation of the testicular protection conferred by damiana (Turnera diffusa Willd.) against amitriptyline-induced testicular toxicity, DNA damage and apoptosis in rats. Biomedicine and Pharmacotherapy, 132, 110819. https://doi.org/10.1016/j.biopha.2020.110819

Vlainich, R., Issy, A. M., \& Sakata, R. K. (2011). Effect of intravenous lidocaine associated with amitriptyline on pain relief and plasma serotonin, norepinephrine and dopamine concentrations in fibromyalgia. The Clinical Journal of Pain, 27(4), 285-288. https://doi.org/10.1097/AJP.0b013e3181ffbfde

Voican, C. S., Corruble, E., Naveau, S., \& Perlemuter, G. (2014). Antidepressant-induced liver injury: A review for clinicians. American Journal of Psychiatry, 171(4), 404-415. https://doi.org/10.1176/appi.ajp.2013.13050709

Vuppalanchi, R., Hayashi, P. H., Chalasani, N., Fontana, R. J., Bonkovsky, H., Saxena, R., ... \& DrugInduced Liver Injury Network (DILIN). (2010). Duloxetine hepatotoxicity: A case-series from the drug-induced liver injury network. Alimentary Pharmacology and Therapeutics, 32(9), 1174-1183. https://doi.org/10.1111/j.1365-2036.2010.04449.x

Zhao, J., Pawar, R. S., Ali, Z., \& Khan, I. A. (2007). Phytochemical investigation of Turnera diffusa. Journal of Natural Products, 70(2), 289-292. https://doi.org/10.1021/np060253r 